\title{
Physicochemical and Sensory Properties of Oat Crackers Incorporated with Cactus Pear Cladodes Flour
}

\author{
Ahmed M. Ihab ${ }^{1}$, Rasha K. Mohamed ${ }^{2}$, Wafaa M. Abozeid ${ }^{2}$, Esmat A. Abou-Arab ${ }^{2}$ \\ ${ }^{1}$ Public Health Department, Faculty of Health Sciences, Al-Qunfda, Umm al-Qura University, KSA \\ ${ }^{2}$ Department of Food Technology, National Research Centre, 33 Buhouth St., Dokki, Giza, Egypt. \\ Received: 12 August 2019/ Accepted 10 Oct. 2019/Publication date: 25 Oct. 2019
}

\begin{abstract}
Cactus pear cladodes flour has numerous health benefits and it is an excellent raw material can be used in bakery products. The presented study were aimed to produce healthy oat crackers incorporated with different levels of cactus pear cladodes flour (CPCF) $(5,7.5,10 \%)$ and studying the effect of incorporated on physicochemical, sensory evaluation and texture attributes of oat crackers. Proximate analysis, total phenolic compound and Radical Scavenging Activity were evaluated for CPCF. While, oat crackers samples were examined for proximate and physicochemical analysis. Hardness, thickness, weight, diameter, spread ratio of oat crackers were evaluated .The color and sensory characteristics of CPCF and oat crackers were carried out. The result showed that CPCF high in total phenolic content $1985 \mathrm{mg} / 100 \mathrm{gm}$ flour and DPPH radical scavenging activity $67 \%$, HPLC analysis observed that there are 7 phenolic compounds (Gallic acid, Chlorogenic acid, Caffeic acid, Syringic acid, Ellagic acid, Coumaric acid and Vanillin) and 5 flavonoids (Catechin, Methyl gallate, Rutin, Naringenin and Pyro catechol).Crude fiber in oat crackers significantly increased with increasing of level cactus pear cladodes flour. Results showed that with increasing of CPCF incorporation level yellow color decreased toward a greenish color. Also, there is a significant decrease in crackers weight with increasing of CPCF level from 2.36 to $1.21 \mathrm{gm}$. Highest sensory and acceptability scores was observed the CPCF $7.5 \%$ crackers more than control crackers.
\end{abstract}

Keywords: Cactus pear cladodes flour, crackers, color parameters, antioxidant ability, sensory attributes

\section{Introduction}

There is a lot of interest in developing the natural products and healthy foods, as well as put a stop of diseases (Prasad et al., 2012).

Prickly pear cactus as a fruit widely distributed in arid and semi-arid regions. It originated from United States, Mexico, and South America (Chougui et al., 2013). It has been cultivated as food for human's nutrition and farm animals (Synman, 2006). People eat cladodes as vegetables because they are soft and fibrous. It have the same nutritional value of vegetables and leaves. Chemical composition of prickly pear cactus stems or "pads" (technically referred to as cladodes) is rich in water $(85 \%-92 \%)$ and comparable to some vegetables, carbohydrates, protein, vitamin $\mathrm{C}$ and $\mathrm{b}$ carotene. Cladodes possess highly health benefits because it's a rich source of bioactive and functional compounds (Giovanna et al., 2009, El-Mostafa et al., 2014; El Kossori et al., 1998).

Cactus cladodes possess a high content of fiber, such as mucilage, cellulose, hemicellulose, pectin, and lignin which capable of improving lipids and sugars metabolism (Ayadi et al., 2009). Generally these polysaccharides are categorized as soluble dietary fiber, boosting control of glucose and modified renal water and sodium handling in type 2 diabetes patients; hence, they has the ability to absorb great portions of water, producing mucilaginous or sticky colloids, an controlling the absorption of various organic molecules (Bensadón et al., 2010).

Wherefore, polyphenols recently received a particular attention from scientific world as they demonstrated antioxidant properties in vitro, simultaneously it has a preventative effect on cancer, and the capacity for curing and preventing cardiovascular disorders, inflammatory and allergic diseases (Rothwell et al.,2017). However, it could help in decreasing the level of cholesterol and suppressing hypercholesterolemia (Diaz et al., 2017)

Corresponding Author: Rasha K. Mohamed, Department of Food Technology, National Research Centre, 33 Buhouth St., Dokki, Giza, Egypt. E-Mail: rasha_km3@yahoo.com. 
Dietary fiber such as cellulose, hemicelluloses, pectin, lignin, gums, etc. have a resistant to digestive enzymes such as cellulose, hemicelluloses, pectin, lignin, gums, etc. (Periago et al., 1993 ). Species of the plant and maturity stage have an effect on $\mathrm{f}$ fiber content of food. It is noticeable that plant seeds, berries, fruit skins and the bran layers of cereal grains ordinarily consist of high level of fiber (Sáenz, 1997). The fiber health benefits related to protection against diabetes, treatment of gastrointestinal disorders, diseases related to low dietary fiber intake, reduction of glucose level in the blood, anti-hyperlipidemic and anti-hypercholesterolemic effects (Gebremariam et al., 2006).

Lately, cactus pear cladodes are drying to produce flour which suggested to be viable nutritional alternative can be used as food ingredient (in corn tortillas) or as a nutritional supplement (powder, capsule or tablet). The benefits of the drying procedure are controlling the microbial growth, lowering costsof storage and transportation, as well as concentrating of nutrients (Kwok et al., 2004; Torrecilla et al, 2005).

Oats got an increased concern in human nutrition research because of their benefits such as consisting of an excellent protein compared to other cereals, being a good source of essential unsaturated fatty acids minerals, and antioxidants (Sangwan et al, 2014). However, $\beta$-glucan, a soluble dietary fiber present mostly in aluerone layer cell wall of oat grain and slightly in its endosperm. It is considered the main component of oats which possess a lot of health benefits (Hareland and Manthey, 2003).

Oats used as food ingredient in several food products including infant foods, bread (Zhang et al. 1998), breakfast cereals (Ryan et al., 2011) and biscuits (Ballabio et al., 2011).

Crackers are a versatile thin and crispy food that can attract a wide range of consumer expectations. They considered as a quick snack with low contents of moisture, sugar, and fat. (Ahmed and Abozed, 2015)

Novel functional snack foods, especially bakery products from the food industry (with potential health benefits) are in high demand by consumers. Numerous studies have assessed the production of bakery products (bread, biscuits, cookies and crackers) with health promoting ingredients (Venkatachalam and Nagarajan, 2017).

The objectives of this study were to produce healthy oat crackers incorporated with different levels of cactus pear cladodes flour (CPCF) a rich source of bioactive compounds and studying the effect of incorporated on sensory flavor and texture attributes of oat crackers

\section{Material and Method}

\section{Preparation of cactus pear cladodes flours (CPCF)}

The cactus pear cladodes were washed with distilled water and disinfected using commercial $10 \%$ sodium hypochlorite solution in order to eliminate microorganisms. The thorns were removed manually and the pads were cut into small slices in order to facilitate the drying process. The prickly pads were then dried for $12 \mathrm{~h} / 50{ }^{\circ} \mathrm{C}$ kept in polyethylene bags and stored at $4{ }^{\circ} \mathrm{C}$. The dried pads were ground to flour.

\section{Proximate analysis}

Cactus pear cladodes flour (CPCF) and oat crackers samples were analyzed for moisture, proteins, fat, crude fiber, carbohydrate and ash contents according to the methods described by AOAC, (2000).

Flour samples (DCF and WF) were analyzed for moisture (Standard oven dry method), proteins (Kjeldahl method), fat (Soxhlet extraction), crude fiber (Weende method), carbohydrate content and ash content according to the methods prescribed by AOAC, 1999 Flour samples (DCF and WF) were analyzed for moisture (Standard oven dry method), proteins (Kjeldahl method), fat (Soxhlet extraction), crude fiber (Weende method), carbohydrate content and ash content according to the methods prescribed by AOAC, 1999 Flour samples (DCF and WF) were analyzed for moisture (Standard oven dry method), proteins (Kjeldahl method), fat (Soxhlet extraction), crude fiber (Weende method), carbohydrate content and ash content according to the methods prescribed by AOAC, (1999). Flour samples (DCF and WF) were analyzed for moisture (Standard oven dry method), proteins (Kjeldahl method), fat (Soxhlet extraction), 
crude fiber (Weende method), carbohydrate content and ash content according to the methods prescribed by AOAC, (1999).

\section{Total phenolics}

Total phenolics were determined for cactus pear cladodes flour (CPCF) by Folin-Ciocalteu method of Singleton et al. (1999). The stock solutions included 1:10 of Folin-Ciocalteu reagent, and $7.5 \%$ sodium carbonate. The working solution was prepared by mixing $1.5 \mathrm{~mL}$ of diluted FolinCiocalteu reagent with $0.2 \mathrm{~mL}$ of cladode extracts. After $5 \mathrm{~min} 1.5 \mathrm{~mL}$ sodium carbonate was added. The absorbance was measured at $725 \mathrm{~nm}$ after $30 \mathrm{~min}$ of reaction. The change in absorbance between the final reading selected and the blank reading was calculated for each sample. Results are expressed in $\mathrm{mg}$ Gallicacid $\mathrm{mL}^{-1}$ of juice. The concentration of Gallic acid as standard was between 10 and 500 $\mathrm{mM}$ in methanol. The experiment was carried out in triplicate.

\section{Assay of DPPH Radical Scavenging Activity}

Antiradical activity was evaluated by measuring the scavenging activity of CPCF on the 2, 2diphenyl-1-1-picrylhydrazil (DPPH) radical using the method described by Kirby and Schmidt (1997) with some modifications. Briefly, $500 \mu \mathrm{L}$ of CPCF at different concentrations ranging from 0.05 to $0.6 \mathrm{mg} / \mathrm{mL}$ was added to $375 \mu \mathrm{L}$ of methanol and $125 \mu \mathrm{L}$ of a DPPH solution $(0.2 \mathrm{mM}$ in methanol) as a source of free radicals. These solution mixtures were kept in the dark for $60 \mathrm{~min}$. Scavenging activity was measured by monitoring the decrease in absorbance at $517 \mathrm{~nm}$. BHT (Butylated Hydroxyl Toluene) was used as a positive compound. The DPPH radical-scavenging activity (RSA) was calculated using the following formula:

$$
\mathrm{RSA} \%=\left[\left(\mathrm{Ac}_{-} \mathrm{As}\right) / \mathrm{Ac}\right] \mathrm{x} 100
$$

Where Ac is the absorbance of the control reaction and as is the absorbance of CPCF

\section{HPLC analysis}

Phenolic and flavonoid profiles of cactus pear cladodes flour (CPCF) were determined using HPLC analysis and it was carried out using an Agilent 1260 series. The separation was carried out using Kromasil C18 column ( $4.6 \mathrm{~mm} \times 250 \mathrm{~mm}$ i.d., $5 \mu \mathrm{m})$. The mobile phase consisted of water (A) and $0.05 \%$ tri-fluoroacetic acid in acetonitrile (B) at a flow rate $1 \mathrm{ml} / \mathrm{min}$. The mobile phase was programmed consecutively in a linear gradient as follows: $0 \min (82 \% \mathrm{~A}) ; 0-5 \mathrm{~min}(80 \% \mathrm{~A}) ; 5-8 \mathrm{~min}$ $(60 \% \mathrm{~A}) ; 8-12 \min (60 \% \mathrm{~A}) ; 12-15 \min (85 \% \mathrm{~A})$ and $15-16 \mathrm{~min}(82 \% \mathrm{~A})$. The multi-wavelength detector was monitored at $280 \mathrm{~nm}$. The injection volume was $10 \mu \mathrm{l}$ for each of the sample solutions. The column temperature was maintained at $35^{\circ} \mathrm{C}$.

\section{Preparation of the cracker formulations}

Four formulations of crackers were prepared. Four formulations included a control, and three oat crackers substituted with 5, 7.5 and $10 \%$ CPCF. Oat crackers prepared by blended $75 \mathrm{~g}$ of oat flour and $40 \mathrm{gm}$ of wheat flour then added $40 \mathrm{ml}$ oil and $70 \mathrm{ml}$ water, salt and cumin and after mixing the dough will cut into crackers pieces and baked for $15 \mathrm{~min}$ at $170{ }^{\circ} \mathrm{C}$ in oven.

\section{Physical characteristics}

\section{Color measurement}

Color measurement parameters of cactus pear cladodes flour (CPCF) and oat crackers samples (Lightness L*, redness $\mathrm{a}^{*}$ and yellowness $\mathrm{b}^{*}$ ) were carried out using a color flex spectrocolorimeter (Hunter Associates Laboratory Inc., Reston, VA). L* value indicates the lightness, 0-100 representing dark to light, $a^{*}$ value gives the degree of the green-red color, with a higher positive $a^{*}$ value indicating more red. The $b^{*}$ value indicates the degree of the blue-yellow color, with a higher positive $b^{*}$ value indicating more yellow.

The hardness was analyzed by the peak force $(\mathrm{N})$ test using a texture machine (CT3 Texture Analyzer, Brookfield, Stuttgart, Germany) equipped with a blade probe. Physical properties of the snack crackers were determined as described by Baljeet et al. (2010). The diameter of snack crackers was measured by laying six snack crackers edge to edge with the help of a scale rotating them $90^{\circ}$ and again measuring the diameter of six snack crackers $(\mathrm{cm})$ and then taking the average value. Thickness 
was measured by stacking six snack crackers on top of each other and taking average thickness $(\mathrm{cm})$. The weight of crackers was measured as average values of four individual snack crackers with the help of a digital weighing balance. Spread ratio was calculated by dividing the average value of the diameter by average value of the thickness of snack crackers.

\section{Sensory analysis}

Sensory attributes of the oat crackers, namely color, taste, crispness, odor, appearance and overall acceptability, were determined by using a 9-point hedonic scale, in which the lowest value (1) stands for extreme dislike and the highest value (9) represents an extreme liking. During the sensory evaluation, crackers of each experimental type were placed separately on plastic plates that were labelled randomly with three-digit codes. Prior to each tasting a sample, lemon water was served to the panelists to neutralize their mouth feel, in order to maintain comparable testing over a sequence of samples (Venkatachalam and Nagarajan, 2017).

\section{Statistical analysis}

Statistical analyses were used to compare the results obtained in the replications and the data were expressed as the mean standard deviation (SD). All analysis was performed by Statistical Analysis System (SAS, 2008).

\section{Results and Discussion}

\section{Proximate composition of cactus pear cladodes flour (CPCF)}

Proximate composition of CPCF which obtained after drying for $12 \mathrm{~h}$ at $50^{\circ} \mathrm{Cin}$ convection oven presented in Table 1 it contained $2.99 \%$ moisture, $6.35 \%$ protein, $1.23 \%$ oil, $19.37 \%$ ash, 7.90 $\%$ fiber and $62.29 \%$ carbohydrates. These results are nearly similar to those reported by LópezCervantes et al. (2011).

Table 1: Proximate analysis of cactus pear cladodes flours $\mathrm{g} / 100 \mathrm{~g}$ dry weight.

\begin{tabular}{cc}
\hline Component & \% \\
\hline Moisture & $2.99 \pm 0.01$ \\
Protein & $6.35 \pm 0.35$ \\
Oil & $1.23 \pm 0.20$ \\
Ash & $19.37 \pm 0.23$ \\
Fiber & $7.90 \pm 0.10$ \\
Carbohydrates* & $62.29 \pm 0.65$ \\
\hline
\end{tabular}

Data are expressed as means \pm SD (by triplicate).

*Carbohydrates obtained by difference.

\section{Total Phenolic Compounds (TPC) and DPPH Radical Scavenging Activity}

The result of total phenolic compound content of cactus pear cladodes flours (CPCF) in (Table 2) showed that there is a high total phenolic content $1985 \mathrm{mg} / 100 \mathrm{~g}$ slightly lower compared to the findings of Msaddak et al., (2015).

Cladodes of the same species; differences may be related to the harvesting season and the geographical area. Phenolic compounds are mostly responsible for the antioxidant properties and various studies concerning find natural antioxidants from inexpensive sources (Dziki et al., 2014).

Table 2: Total Phenol compound and DPPH Radical Scavenging Activity of cactus pear cladodes flours

\begin{tabular}{ccc}
\hline Sample & $\begin{array}{c}\text { Total phenolics Gallic acid } \\
\mathbf{m g} / \mathbf{1 0 0 g m}\end{array}$ & Radical Scavenging Activity \\
\hline CPCF & $1985 \pm 45$ & $67 \%$ \\
\hline
\end{tabular}

DPPH radical scavenging activity also reported in Table 2, the antioxidant activity DPPH was $67 \%$. The antioxidant activity of phenolic compounds may related to free radicals neutralization in the start of oxidation processes or from the ending of radical chain reactions. Also the antioxidant activity of phenolic compounds possess a high tendency to chelate metals. Scavenging ability of 
phenols on free radicals related to possess of hydroxyl groups (Heim et al., 2002). Studies presented a good correlation between the phenols and antioxidant activity (Gulcin et al., 2004).

\section{HPLC analysis}

The HPLC elution profile of CPCF shown in Figure 1 and Table 3 revealed the presence of phenolic acids and flavonoids identified at $280 \mathrm{~nm}$.

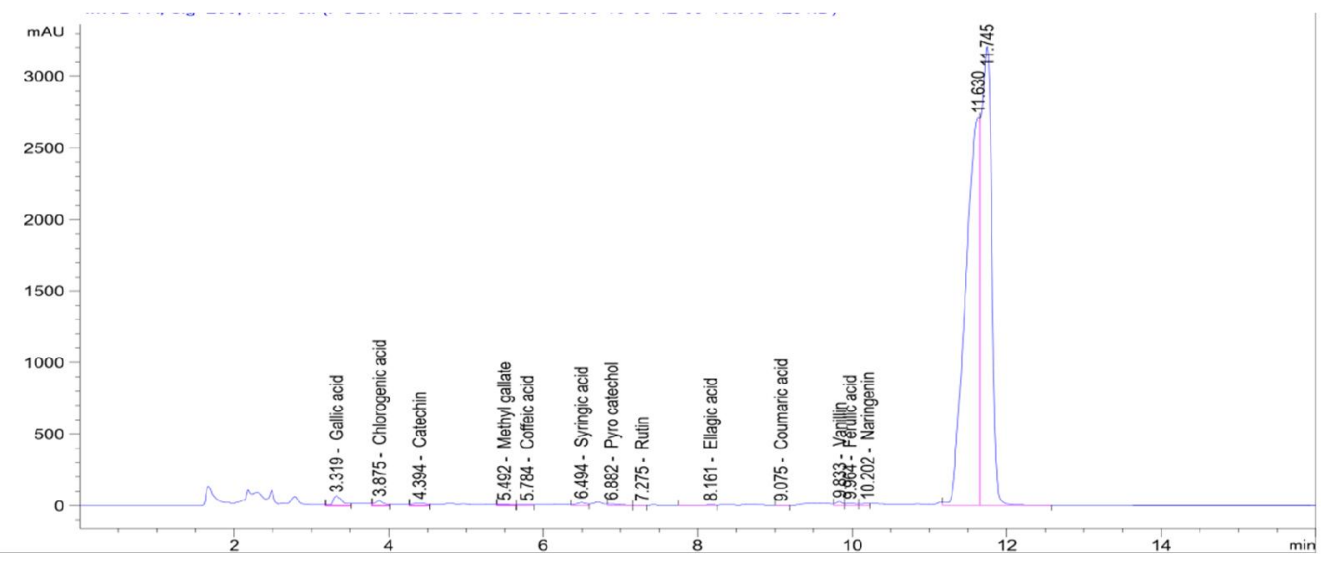

Fig. 1: HPLC Chromatogram of phenolic and flavonoids in $\mathrm{CPCF}$

Table 3: Phenolic compound contents in cactus pear cladodes flour

\begin{tabular}{cc}
\hline Compounds & $\boldsymbol{\mu g} / \mathbf{g m}$ \\
\hline Gallic acid & 650.34 \\
Chlorogenic acid & 437.77 \\
Catechin & 706.21 \\
Methyl gallate & 37.30 \\
Coffeic acid & 44.47 \\
Syringic acid & 64.21 \\
Pyro catechol & 245.49 \\
Rutin & 75.62 \\
Ellagic acid & 69.89 \\
Coumaric acid & 8.17 \\
Vanillin & 60.14 \\
Ferulic acid & 98.64 \\
Naringenin & 141.62 \\
\hline
\end{tabular}

There were observed that 13 compounds were found and presented in Table 3 . They are 7 phenolic compounds (Gallic acid, Chlorogenic acid, Caffeic acid, Syringic acid, Ellagic acid, Coumaric acid and Vanillin) and 5 flavonoids (Catechin, Methyl gallate, Rutin, Naringenin and Pyro catechol).

\section{Proximate composition of oat crackers with different levels of cactus pear cladodes flour CPCF}

Formula of oat crackers was substituted with different levels of CPCF5, 7.5 and 10\%. Proximate analysis in Table 4 were determined for control and substituted samples. Oat crackers has low moisture content ranged from $1.10 \%$ to $1.67 \%$ it is means that the moisture content increasing with an increase of substitution level of cladodes flour. This is because of the higher water absorption capacity of cladodes flour $(4.5 \mathrm{ml} / \mathrm{g})$. Also this was expected because of the high fiber content of cladodes flour as reported by El-Safy, (2013).

The protein content was ranged from 7.90 to $8.43 \%$.Oil content was ranged from 15.14 to $16.04 \%$. The ash content in the oat crackers significantly increased $(\mathrm{p} \leq 0.05)$ with increasing substitution level of cladodes flour that's due to the higher level of ash content of cactus pear cladodes flour.The dietary fiber is an important factor because it has been showed beneficial in human health (Slavin, 2008). Cladodes fiber probably may affect the gastrointestinal mucosa regeneration (Galati et 
al., 2003). Crude fiber in oat crackers was ranged from 2.23 to $3.42 \%$ it was observed that crude fiber significantly increased with increasing of level cactus pear cladodes flour. Based on these results, the use of cactus pear cladodes flour in oat crackers may provide a nutritional benefit to the consumers.

Table 4: Proximate analysis of oat crackers prepared by different levels of CPCF $(5,7.5$ and $10 \%)$

\begin{tabular}{ccccc}
\hline Component & Control & CPCF 5 \% & CPCF 7.5 \% & CPCF 10\% \\
\hline Moisture & $1.10^{\mathrm{a}} \pm 0.10$ & $1.50^{\mathrm{b}} \pm 0.02$ & $1.47^{\mathrm{b}} \pm 0.05$ & $1.67^{\mathrm{c}} \pm 0.03$ \\
Protein & $7.90^{\mathrm{a}} \pm 0.01$ & $8.13^{\mathrm{bc}} \pm 0.16$ & $8.22^{\mathrm{cd}} \pm 0.22$ & $8.43^{\mathrm{d}} \pm 0.11$ \\
Oil & $15.14^{\mathrm{a}} \pm 0.12$ & $15.48^{\mathrm{ab}} \pm 0.42$ & $15.67^{\mathrm{bc}} \pm 0.21$ & $16.04^{\mathrm{c}} \pm 0.04$ \\
Ash & $7.48^{\mathrm{a}} \pm 0.03$ & $8.11^{\mathrm{b}} \pm 0.10$ & $10.32^{\mathrm{c}} \pm 0.33$ & $11.47^{\mathrm{d}} \pm 0.07$ \\
Crude fiber & $2.23^{\mathrm{a}} \pm 0.06$ & $2.74^{\mathrm{b}} \pm 0.07$ & $3.00^{\mathrm{c}} \pm 0.01$ & $3.42^{\mathrm{d}} \pm 0.07$ \\
Carbohydrates & $66.15^{\mathrm{d}} \pm 0.05$ & $64.04^{\mathrm{c}} \pm 0.75$ & $61.32^{\mathrm{b}} \pm 0.24$ & $58.98^{\mathrm{a}} \pm 0.11$ \\
\hline
\end{tabular}

Data are expressed as means \pm SD (by triplicate).

Different letters in the same row indicate significant differences $(\mathrm{P} \leq 0.05)$ among samples.

*Carbohydrates obtained by difference.

\section{Color analysis}

The color parameters of CCPF and oat crackers incorporated with varied level of CPCF samples are shown in Table5 and Fig 2.

There was a significant decreasing trend of lightness along with the increasing substitution level of jojoba protein isolate



Fig. 2: a) CPCF b) Control c) CPCF 5\% d) CPCF $7.5 \%$ e)CPCF $10 \%$

Table 5: Color parameters of the cactus pear cladodes flour and oat crackers incorporated with varied level of cactus cladodes flour

\begin{tabular}{cccc}
\hline Samples & L & a & b \\
\hline CPCF & $69.03^{\mathrm{d}} \pm 0.02$ & $1.32^{\mathrm{a}} \pm 0.02$ & $25.04^{\mathrm{c}} \pm 0.01$ \\
Control & $63.71^{\mathrm{c}} \pm 0.45$ & $4.12^{\mathrm{c}} \pm 0.17$ & $22.84^{\mathrm{a}} \pm 0.18$ \\
CPCF 5 \% & $53.28^{\mathrm{c}} \pm 0.03$ & $4.64^{\mathrm{b}} \pm 0.01$ & $23.73^{\mathrm{b}} \pm 0.01$ \\
CPCF 7.5 \% & $61.01^{\mathrm{b}} \pm 0.01$ & $5.12^{\mathrm{d}} \pm 0.01$ & $28.88^{\mathrm{d}} \pm 0.00$ \\
CPCF 10\% & $57.74^{\mathrm{a}} \pm 0.01$ & $6.27^{\mathrm{e}} \pm 0.01$ & $29.47^{\mathrm{e}} \pm 0.47$ \\
\hline
\end{tabular}

Data are expressed as means \pm SD (by triplicate).

Different letters in the same column indicate significant differences $(\mathrm{P} \leq 0.05)$ among samples.

CPCF Color parameters $\mathrm{L}^{*}, \mathrm{a}^{*}$ and $\mathrm{b}^{*}$ values were $69.03,1.32$ and 25.04 respectively. It was observed that there is no significant change in lightness in control oat cracker and the substituted at 5 $\%$ CPCF. There was significant decrease in lightness on $10 \%$ CPCF (57.74) indicated that the crackers get darker compared to control crackers with increasing the substitution level of CPCF to $10 \%$. 
However, data in table 5 showed that with increasing of CPCF incorporation level a* and $b^{*}$ values decreased, which indicates that yellow color decreased toward a greenish color. This could be due to the high level of chlorophyll in CPCF as reported by Msaddak et al. (2015).

\section{Physical characteristics of oat crackers}

The physical characteristics of oat crackers incorporated with different level of CPCF were investigated. Results of the physical characteristics (hardness, thickness, weight, diameter, and spread ratio) of the oat crackers are shown in Table 6.

Table 6: Physical characteristics of oat crackers incorporated with varied level of cactus cladodes flour

\begin{tabular}{ccccccc}
\hline Sample & Fmax (N) & Emax $(\mathbf{m m})$ & Thickness & Weight & Diameter & $\begin{array}{c}\text { Spread } \\
\text { ratio }\end{array}$ \\
\hline Control & $61.81^{\mathrm{c}} \pm 0.01$ & $7.99 \pm 0.01$ & $0.25^{\mathrm{b}} \pm 0.02$ & $2.07^{\mathrm{c}} \pm 0.02$ & $3.87^{\mathrm{a}} \pm 0.15$ & $15.47^{\mathrm{c}} \pm 0.04$ \\
CPCF 5\% & $87.06^{\mathrm{d}} \pm 0.02$ & $9.01 \pm 0.01$ & $0.26^{\mathrm{b}} \pm 0.02$ & $2.36^{\mathrm{d}} \pm 0.02$ & $3.60^{\mathrm{a}} \pm 0.17$ & $14.09^{\mathrm{b}} \pm 0.01$ \\
CPCF 7.5\% & $33.48^{\mathrm{a}} \pm 0.02$ & $8.49 \pm 0.01$ & $0.26^{\mathrm{b}} \pm 0.01$ & $1.54^{\mathrm{b}} \pm 0.02$ & $3.63^{\mathrm{a}} \pm 0.12$ & $13.91^{\mathrm{a}} \pm 0.01$ \\
CPCF 10\% & $53.34^{\mathrm{b}} \pm 0.01$ & $8.98 \pm 0.01$ & $0.18^{\mathrm{a}} \pm 0.02$ & $1.21^{\mathrm{a}} \pm 0.02$ & $3.80^{\mathrm{a}} \pm 0.01$ & $21.38^{\mathrm{d}} \pm 0.02$ \\
\hline
\end{tabular}

Data are expressed as means \pm SD (by triplicate).

Different letters in the same column indicate significant differences $(\mathrm{P} \leq 0.05)$ among samples.

Texture is an important factor of physical characteristics of food product that influences consumer (Durgadevi and Shetty, 2012). Hardness was measured by Texture Analyzer and the result presented in Table 4. The results showed that cracker have F max values between 33.48-87.06 N. F max proposed the compressive strength given to the sample till change occurs in shape and broken. From the results, CPCF 7.5\% has the lowest score of $\mathrm{F}$ max, which explains that it was easy to chew. The highest result of $\mathrm{F}$ max was from CPCF 5\% which preferable not to break easily compared to other crackers. This may be due to level of moisture affected the hardness of samples (Wada and Higo, 2007).

There is no significant difference in thickness between the crackers (CPCF5\% CPCF7. 5\%) thickness compared with control while there is a significant difference between them and CPCF $10 \%$ $(0.18)$.The results showed that the weight of oat crackers ranged from 1.21 to $2.36 \mathrm{gm}$ and there is a significant decrease in crackers weight with increasing of CPCF level. There is no significant difference between crackers in diameter. Changes in diameter and thickness were reflected in spread ratio which was 15.47 for control crackers, these values increased to 21.38 in $10 \%$ CPCF samples.

\section{Sensory evaluation}

There was a significant decreasing trend of lightness along with the increasing substitution level of jojoba protein isolate

Oat crackers incorporated with different level of CPCF were evaluated for their sensory attributes and over all acceptability shown in Table 7. Means scores for the parameters color, odor, taste, texture, crispness, appearance, over all acceptability.

Table 7: Sensory evaluation of oat crackers prepared with incorporated with varied level of Cactus cladodes flour

\begin{tabular}{lccccccc}
\hline & Color & Odor & Taste & Texture & Crispness & Appearance & $\begin{array}{c}\text { Over all } \\
\text { acceptability }\end{array}$ \\
\hline Control & $7.56^{\mathrm{a}}$ & $7.78^{\mathrm{a}}$ & $7.22^{\mathrm{a}}$ & $7.67^{\mathrm{a}}$ & $7.78^{\mathrm{ab}}$ & $7.56^{\mathrm{a}}$ & $7.67^{\mathrm{a}}$ \\
& \pm 0.73 & \pm 1.72 & \pm 1.09 & \pm 1.73 & \pm 1.20 & \pm 1.01 & \pm 1.12 \\
CPCF 5 \% & $7.67^{\mathrm{ab}}$ & $7.67^{\mathrm{a}}$ & $6.78^{\mathrm{a}}$ & $7.11^{\mathrm{a}}$ & $7.00^{\mathrm{a}}$ & $7.22^{\mathrm{a}}$ & $7.33^{\mathrm{a}}$ \\
& \pm 0.87 & \pm 1.58 & \pm 1.30 & \pm 1.36 & \pm 1.58 & \pm 1.48 & \pm 1.32 \\
CPCF 7.5 \% & $8.56^{\mathrm{b}}$ & $8.00^{\mathrm{a}}$ & $7.16^{\mathrm{a}}$ & $8.33^{\mathrm{a}}$ & $8.66^{\mathrm{b}}$ & $8.22^{\mathrm{a}}$ & $8.11^{\mathrm{a}}$ \\
& \pm 0.53 & \pm 1.33 & \pm 1.83 & \pm 1.12 & \pm 1.01 & \pm 1.48 & \pm 1.45 \\
CPCF 10 \% & $8.00^{\mathrm{ab}}$ & $7.82^{\mathrm{a}}$ & $7.15^{\mathrm{a}}$ & $8.07^{\mathrm{a}}$ & $8.56^{\mathrm{b}}$ & $8.04^{\mathrm{a}}$ & $7.98^{\mathrm{a}}$ \\
& \pm 1.32 & \pm 1.58 & \pm 2.17 & \pm 1.51 & \pm 1.00 & \pm 1.59 & \pm 1.59 \\
\hline
\end{tabular}

Data are expressed as means \pm SD (by triplicate).

Different letters in the same column indicate significant differences $(\mathrm{P} \leq 0.05)$ among samples. 
CPCF $7.5 \%$ crackers showed a highest sensory scores than all samples. Highest color acceptability score was observed the CPCF $7.5 \%$ crackers (8.56) followed by CPCF $10 \%$ cracker (8.00). Control crackers was the lowest color acceptability score (7.56). Although there is no significant difference in odor scores but it was observed that the CPCF $7.5 \%$ crackers achieved the highest score in odor acceptability (8.00). There no difference significant in taste but the control crackers achieved the highest acceptability score (7.22) followed by CPCF $7.5 \%$ crackers and CPCF $10 \%$ crackers (7.16 and 7.15 respectively).Texture and crispness features are important characteristics of crackers CPCF $7.5 \%$ crackers was the highest score in texture and crispness $(8.33$ and 8.66 respectively).CPCF $7.5 \%$ crackers take the same trend in appearance and over all acceptability scores (8.22 and 8.11 respectively). Sensory evaluation showed that CPCF $7.5 \%$ crackers achieved the highest score of acceptability and sensory parameters.

\section{Conclusion}

Proximate and physicochemical analysis of cactus pear cladodes flour, showed richness in bioactive and functional biomolecules. The incorporation of CPCF in oat crackers, upgraded their functional characteristics. Addition of cactus pear cladodes flour assumed to be very promising functional healthy product. Sensory evaluation showed at $7.5 \%$ level did not show any undesirable attributes or texture response and the crackers stay acceptable and get a high scores compared to control. From the obtained results, it can be recommended that pear cladodes flour could be commercially used by food manufacturing industries as potential source of dietary fiber, and antioxidants.

\section{References}

Ahmed, Z.S. and S.S. Abozed, 2015. Functional and antioxidant properties of novel snack crackers incorporated with Hibiscus sabdariffa by-product. J. Adv. Res. 6:79.

AOAC, 2000. Official Methods of Analysis of AOAC International (Hurwitz, W.ED.) $17^{\text {th }}$ Edition, Suite 500, 481 North Fredric avenue Gaithersburg, MD, USA.

Ayadi, M.A., W. Abdelmaksoud, M. Ennour and H. Attia, 2009. Cladodes from Opuntia ficus-indica as a source of dietary fiber. Effect on dough characteristic and cake making. Ind. Crops Prod., $30,40-47$.

Baljeet, S.Y, B.Y. Ritika, and L.Y. Roshan, 2010. Studies on functional properties and incorporation of buckwheat flour for biscuit making. International Food Research Journal, 17, 1067-1076

Ballabio, C., F. Uberti, S. Manferdelli, E. Vacca, G. Boggini, R. Redaelli, C. Catassi, E. Lionetti, E. Penas, and P. Restani, 2011. Molecular characterization of 36 oat varieties and in vitro assessment of their suitability for celiac's diet. J Cereal Sci., 54:110-115.

Bensadón, S., D. Hervert-Hernández, S.G. Sáyago-Ayerdi, I. Goni, 2010. By-products of Opuntia ficus- indica as a source of antioxidant dietary fiber. Plant Foods Hum. Nutr., 65, 210-216.

Chougui, N., H. Louaileche, S. Mohedeb, Y. Mouloudj, Y. Hammaoui, and A. Tamendjari, 2013. Physico-chemical characterization and antioxidant activity of some Opuntia ficus-indica varieties grown in North Algeria. Afr. J. Biotechnol., 12, 299-307.

Diaz, D.S.S., B.A. Rosa, C. Héliès-Toussaint, F. Guéraud, and A. Nègre-Salvayre, 2017. Opuntia spp.: Characterization and benefits in chronic diseases. Oxid. Med. Cell. Longev., 2017:1-17.

Durgadevi M. and P.H. Shetty, 2012. Effect of Ingredients on Texture Profile of Fermented Food, Idli. APCBEE Procedia, 2, $190-198$.

Dziki, D, R. Rozyło, U. Gawlik-Dziki, and M. Swieca, 2014. Current trends in the enhancement of antioxidant activity of wheat bread by the addition of plant materials rich in phenolic compounds. Trends Food Sci Tech., 40:48-61.

El Kossori, R. L., C. Villaume, E. E. El Boustani, Y. Sauvaire and L. Méjean, 1998. Composition of pulp, skin and seeds of prickly pears. Plant Foods Hum Nutr., 52:263-270 .

El-Mostafa, K., Y. El Kharrassi, A. Badreddine, P. Andreoletti, J. Vamecq, M.S. El Kebbaj, N. Latruffe, G. Lizard, B. Nasser, and M. Cherkaoui-Malki, 2014. Nopal Cactus (Opuntia ficusindica) as a source of bioactive compounds for nutrition, health and disease. Molecules 19, $14879-14901$ 
ElSafy, S., 2013. Evaluation and utilization of cladodes flour in formulating functional sponge cake. World Applied Sciences Journal 27(4), 512-523.

Galati, E.M., M.R. Mondello, D. Giufferida, G. Dugo, N. Miceli, S.Pergolizzi, and M. F. Taviano 2003. Chemical characterization and biological effects of Sicilian Opuntia ficus-indica (L.) Mill. Fruit juice: antioxidant and antiulcerogenic activity. J Agric Food Chem., 51:4903-4908.

Gebremariam T, S. Melaku, and A. Yami, 2006. Effect of different levels of cactus (Opuntia ficusindica) inclusion on feed intake, digestibility and body weight gain in tef (Eragrostis tef) strawbased feeding of sheep. Anim. Feed Sci. Tech., 131:42-51

Giovanna, G., M.L. Parker, R.N. Bennett, J. Robertson, G. Mandalari, A. Narbard, R.B. Lo Curto, G. Bisignano, C.B. Faulds, and K.W. Waldron, 2009.Anatomical, chemical, and biochemical Characterization of cladodes from Prickly Pear (Opuntia ficus-indica (L.)Mill. J. Agric. Food. Chem. 57, 10323-10330.

Gülçin, I., G.Şatí., Ş.Beydemir, and Ö.İ. Küfrevioğlu, 2004. Evaluation of the in vitro antioxidant properties of extracts of broccoli (Brassica oleracea L.)Italian Journal of Food Sciences, 16, p. 17

Hareland, G. A., and F. A. Manthey, 2003. Oats. Pages 4213-4220 in: Encyclopedia of Food Sciences and Nutrition. B. Caballero, L. Trugo and P. Finglas, eds. Elsevier Science Limited: St. Louis, MO.

Heim, K.E., A.R. Taigliaferro, and D.J. Bobilya, 2002. Flavonoid antioxidants: chemistry, metabolism and structure-activity relationships. The Journal of Nutritional Biochemistry, 13: 572-584.

Kirby, A.J., and R.J. Schmidt (1997. The antioxidant activity of Chinese herbs foreczema and of placebo herbs-I. J Ethnopharmacol. 56:103-110.

Kwok, B.H.L., C. Hu, T.Durance, and D.D. Kitt, 2004. Dehydration techniques affect phytochemical contents and free radical scavenging activities of Saskatoon berries (Amelanchier alnifolia Nutt.. Journal of Food Science, v. 69, p. 122-126.

López-Cervantes, J., D. I. Sánchez-Machado, O.N. Campas-Baypoli, and C. Bueno-Solano 2011.Functional properties and proximate composition of cactus pear cladodes flours. Ciênc. Tecnol. Aliment. Campinas, 31(3): 654-659.

Msaddak, L., R. Siala, N. Fakhfakh, M. A. Ayadi, M. Nasri and N. Zouari, 2015. Cladodes from prickly pear as a functional ingredient: effect on fat retention, oxidative stability, nutritional and sensory properties of cookies, International Journal of Food Sciences and Nutrition, Int J Food Sci. Nutr, Early Online: $1-7$.

Periago, M.J., G. Ros, G. López, M.C. Martínez, and F. Rincón (1993. The dietary fiber components and their physiological effects. Rev. Esp. CienciaTecnol. Aliment. , 33:229-246

Prasad, K.N., K.W. Kong, . N.S. Ramannan, A. Azrina, and I. Amin, 2012. Selection of experimental domain using two level factorial design to determine extract yield, antioxidant capacity, phenolic and flavonoids from Mangiferapajang Kosterm Sep. Sci. Technol., 47, pp. 2417-2423.

Rothwell, J.A., V. Knaze, and R. Zamora-Rosa, 2017) Polyphenols: Dietary assessment and role in the prevention of cancers. Curr. Opin. Clin. Nutr. Metab. Care., 20, 512-521.

Ryan, L., P.S. Thondre, and C.J.K. Henry, 2011. Oat-based breakfast cereals are a rich source of polyphenols and high in antioxidant potential. J. Comp. Food Anal. 24:929-934.

Sáenz, H.C., 1997. Cladodes: A source of dietary fiber. J. Prof. Assoc. Cactus. Dev., 2:117-123

Sangwan, S., R. Singh, and S. K. Tomar, 2014. Nutritional and functional properties of oats: An update. J. Mol. Biol. 1:003-014.

SAS System for Windows (Statical Analysis System), 2008. Version 9.2. Cary, USA: SAS Institute Inc.

Singleton, V.L., R. Orthofer, and R.M. Lamuela, 1999.Analyses of total phenols and other oxidation substances and antioxidants by means of folin-Ciocalteu reagent. Oxidant Antioxidants Part A 299, 152-178.

Slavin, J.L., 2008. Position of the Amercian Dietetic Association: Health implications of dietary fiber. J., Amer. Dietetic Asso., 108: 1716-1731.

Synman, H.A., 2006. A greenhouse study on root dynamics of cactus pears, Opuntia ficus-indica and O. robusta. J. Arid. Environ. 65, 529-542. 
Torrecilla, J. S., M. J. Aragón and C. M. Palancar 2005.Modeling the drying of a high-moisture solid with an artificial neural network. Industrial \& Engineering Chemistry Research, v. 44, p. 8057 8066.

Venkatachalam, K. and M. Nagarajan, 2017. Physicochemical and Sensory Properties Of Savory Crackers Incorporating Green Gram Flour To Partially Or Wholly Replace Wheat Flour Ital. J. Food Sci., Vol. 29, 599-612.

Wada, Y. and A. Higo, 2007. Effect of moisture and temperature on the texture properties of commercial confectionery. Nippon Shokuhin Kagaku Kogaku Kaishi, 54(6), 253-260.

Zhang, D., W.R. Moore, and D.C. Doehlert, 1998. Effects of oat grain hydrothermal treatments on wheat-oat flour dough properties and breadbaking quality. Cereal Chem. 75:602-605 